\title{
Changes in Vocational Pedagogy after Restoration of Estonian Independence
}

\author{
Reeli Liivik and Meidi Sirk
}

\begin{abstract}
After the end of the Soviet regime and the restoration of Estonian independence in 1991, significant changes in vocational education took place, which were influenced by social and economic transformations. Soviet centralised and production-related vocational education became school-based because large factories closed and the economy changed. Changes in the labour market demanded different skills and specialties and different pedagogical approaches to prepare people for work. Vocational schools and teachers faced many challenges. In this article, we discuss the significant national changes that took place in vocational education after the collapse of the Soviet regime and before Estonia joined the European Union as well as the changes long-serving vocational teachers experienced in vocational pedagogy. Our research is qualitative, using a phenomenological approach based on semi-structured interviews with nine long-serving vocational teachers. The main results show that there have been many changes on the national level in vocational education but not all influenced teachers' daily teaching. Also, many changes occurred that disturbed practice such as shortened study periods or reorganisation of the school network. Vocational teachers also had positive experiences related to curricula development and standardisation, which created a common basis and understanding of learning content.
\end{abstract}

Keywords: vocational pedagogy, vocational education, vocational schools, changes in vocational education and training

\section{Introduction}

In this article, we focus on changes in Estonian vocational pedagogy after the restoration of independence in 1991 until joining the European Union in 2004. We define vocational pedagogy as a pedagogical discipline that deals with wider issues of vocational education and training (VET), including organisation, principles, and financing of VET; cooperation and relationships between the worlds of work, vocations, and education; ${ }^{1}$ and development of youth and adult competences for various types of careers. ${ }^{2}$ It also refers to results from the many decisions that vocational teachers made during teaching by adjusting

1 CEDEFOP, Research Paper No. 47 'Vocational Pedagogies and Benefits for Learners: Practices and Challenges in Europe', Luxembourg, Publications Office of the European Union, 2015.

2 R. Arnold, A. Krämer-Stürzl, Berufs-und Arbeitspädagogik: Leitfaden der Ausbildungspraxis in Produktions-und Dienstleistungsberufen [Vocational and work pedagogy: Guidelines for training practices in production and service occupations], Berlin, Cornelsen Girardet, 1999, p. 17. 
their approaches to meet the needs of students. ${ }^{3}$ Vocational teachers played an important role in the implementation of VET reforms: ${ }^{4}$ they not only carried out the changes in VET but were also affected by them through improvement of knowledge and skills needed to meet the expectations that accompanied the changes. ${ }^{5}$ Various studies (in Estonian) have emphasised the changes that influenced VET teachers' work such as cooperation between businesses, other schools and international partners, and changes in teaching practices and students. ${ }^{6}$

After the restoration of independence in Estonia in 1991, significant changes in vocational education were influenced by social and economic transformations. Transition from the Soviet regime to a democratic society demanded remarkable developments. Changes in the labour market demanded different skills and specialties and different pedagogical approaches to prepare people for work. The entire VET institutional infrastructure had to be rebuilt in a very short time. Soviet centralised and production-related vocational education became school-based because changes in the economy shut down large factories; ${ }^{7}$ cooperation with new, small, and unstable enterprises began. The main changes affected laws and regulations on the organisation of vocational education, financing principles, re-organisation of the school network, forms and levels of study, and organisation of practice. ${ }^{8}$

Our study discusses the significant national changes that took place in vocational education after the collapse of Soviet regime until joining the European Union and the changes long-serving vocational teachers experienced in vocational pedagogy.

3 CEDEFOP, Research Paper No. 47 'Vocational Pedagogies and Benefits for Learners: Practices and Challenges in Europe,' Luxembourg, Publications Office of the European Union, 2015.

${ }^{4}$ CEDEFOP, Trends in VET Policy in Europe 2010-12: Progress Towards the Bruges Communiqué, Luxembourg, Publications Office of the European Union, 2012.

5 M. Singh, 'Investing the Changes in Teacher Professional Learning: A Case Study of QMEA Schools, Cross Cultural Communication, vol. 7, no. 2, 2011, pp. 63-72.

${ }^{6}$ K. Loogma, 'The Situation of VET Teachers in Estonia,' in S. Kirpal (ed.), Changing Roles and Competences of VET Teachers and Trainers. Final Report. National Summaries of Interview Results, vol. 2, University of Bremen, 2010, pp. 97-116; M. Ümarik, S. Rekkor, 'Diversification of Students and Professional Roles of Vocational Teachers: Teachers' Individual Approaches to Negotiate Work Identities', in J. Mikk, M. Veisson, P. Luik (eds.), Change in Teaching and Learning, vol. 5, Frankfurt am Main, Peter Lang, 2013, pp. 9-26; M. Sirk, R. Liivik, K. Loogma, 'Changes in the Professionality of Vocational Teachers as Viewed Through the Experiences of Long-serving Vocational Teachers in Estonia, Empirical Research in Vocational Education and Training, vol. 8, no. 13, 2016, pp. 1-26.

7 K. Loogma, 'The Situation of VET Teachers in Estonia,' in S. Kirpal (ed.), Changing Roles and Competences of VET Teachers and Trainers. Final Report. National Summaries of Interview Results, vol. 2, University of Bremen, 2010, pp. 97-116.

8 1996-2006: Kutseharidus [1996-2006: Vocational education], Tallinn, Statistikaamet, 2007, p. 48. 
We used qualitative research strategies based on analysis of documents and on personal experiences using the phenomenological approach. ${ }^{9}$ Data were collected in 2014 in semi-structured interviews that lasted 1-2 hours. Questions focussed on discussion of becoming a vocational teacher, duties of a vocational teacher, major changes in VET over the last two decades experienced by teachers, and the effects of political changes and reforms on teachers' work. The sample involved nine vocational teachers between the ages of 52 and 72 who had 23 to 39 years of pedagogical experience. The interviewees taught various subjects (clothing manufacturing, food processing, agriculture, etc.). The thematic analysis process was used to analyse the data. ${ }^{10}$ All interviews were saved and transcribed. In the course of reading the interviews texts, notes and samples were taken, highlighting issues significant for teachers and relevant to vocational pedagogy during this period.

\section{Changes in vocational pedagogy from 1991 to 2004}

At the beginning of the transition period, the VET system was identified as the most difficult area within Estonian educational policy because it faced many challenges - adaptation to a market economy, implementation of modern curricular and education structures, and decline in participation and social status. ${ }^{11}$ After 1992, production in Estonia fell by 30\% per year, agriculture collapsed, ${ }^{12}$ and the Soviet-style vocational education system, which was tied to a planned economy and production, was replaced with a school-based one. In the Soviet system, vocational training in the schools was based on the needs of state-run companies (factories, collective farms, etc.). Additionally, these places provided training in their own workshops, and upon graduating from a VET school, the graduates' workplaces were already determined. School-based vocational training meant that up to half of the studies took place in the school environment, providing theoretical knowledge, and was supplement primarily by practice in school workshops and later at a workplace. But, the school-based system met with new problems - newly-established companies had no interest, time, or reasons for involvement with vocational education, and there was no legislation tying businesses to the VET system. ${ }^{13}$

${ }^{9}$ J. Smith, M. Larkin, Interpretative Phenomenological Analysis: Theory, Method and Research, London, SAGE Publication, 2009; C. Moustakas, Phenomenological Research Methods, California, SAGE Publications Inc, 1994.

${ }^{10}$ V. Braun, V. Clarke, 'Using Thematic Analysis in Psychology', Qualitative Research in Psychology, vol. 3, no. 2, 2006, pp. 77-101.

${ }^{11}$ Estonia: Overview of the Vocational Education and Training System in 2005, ReferNet Estonia, 2005. Available: https://www.cedefop.europa.eu/files/2005_to_ee.pdf (accessed 11.04.2020)

${ }^{12}$ M. Laar, 'Eesti uus algus' [New beginning of Estonia], in K. Tael (ed.), Eesti reformikogemus teel Euroopa Liitu [Estonia's reform experience on the road to the European Union], Välismisteerium, 2009, p. 9.

${ }^{13}$ R. Neudorf, T. Annus, L. Orro, K. Jõgi, 'National Observatory of Estonia, European Training Foundation', in The VET System in Estonia: Recent Changes, Challenges and Reform Needs, Sofia, Sibi Publishing House, 1997, pp. 19-20. 
The changes in Estonian vocational education took place in several stages, ${ }^{14}$ which will be discussed chronologically through the experiences of longserving teachers.

Liberal adjustment, 1991-1996. The first years of independence were very difficult for vocational education because of the uncertainty about the country's economic development and the passivity of the Ministry of Education in the field of vocational education. ${ }^{15}$ In the early 1990s, liberal adjustment within vocational schools responded to changes in the labour market and the economy. The previous system of practical training was weakened and changed considerably by comprehensive restructuring during privatisation and reorientation from Eastern to Western markets. ${ }^{16}$ Priority in education policy was given to general and higher education, ${ }^{17}$ and developments in VET were quite random. The department responsible for VET in the Ministry of Education was abolished, ${ }^{18}$ so an institution for the governance of VET from 1991-1995 did not even exist. ${ }^{19}$ The entire VET system had to be rebuilt because the previous systems were destroyed, even the things that worked well. Longserving teachers noted that the system of career counselling in particular was abolished, there were no medical or catering services for students, and social workers and school psychologists were lacking:

...in the beginning everything was demolished ... we started to build up ... now we have a head of departments, an activity leader and a social pedagogue - at that time we were also social pedagogues ...

${ }^{14}$ K. Loogma, 'Europeanization in VET Policy as a Process of Reshaping the Educational Space, International Journal for Research in Vocational Education and Training, vol. 3, no. 1, 2016, pp. 16-28.

15 M. Kask, 'Viimaste aastate muudatused Eesti kutseharidussüsteemis ning kavandatavad reformid' [The latest year's changes in Estonian VET system and planned reforms], in Baltimaade kutsehariduse ja - koolituse konverents Euroopa riikide vahelise koostöö tähtsus: 22. ja 23. aprillil 1996 Tallinnas [The conference of VET of Baltic states. The importance of the cooperation between European countries: April 22-23, 1996, Tallinn], Torino, European Training Foundation, 1996, pp. 14-44.

${ }^{16}$ K. Loogma, 'Europeanization in VET Policy as a Process of Reshaping the Educational Space, International Journal for Research in Vocational Education and Training, vol. 3, no. 1, 2016, pp. 16-28; K. Loogma, 'The Situation of VET Teachers in Estonia', in S. Kirpal (ed.), Changing Roles and Competences of VET Teachers and Trainers. Final Report National Summaries of Interview Results, vol. 2, University of Bremen, 2010, pp. 97-116.

17 'Estonia: Overview of the Vocational Education and Training System in 2005' ReferNet Estonia, 2005. Available: https://www.cedefop.europa.eu/files/2005_to_ee.pdf (accessed 11.04.2020)

${ }^{18}$ A. Kõverjalg, 'Kutsehariduse arenguprobleemid' [The development problems of vocational education], Eesti Haridusminimsteeriumi pedagoogiline ajakiri: Haridus [Pedagogical journal of the Estonian Ministry of Education: Education], no. 8, 1991, pp. 2-5; A. Kõverjalg, 'Kutsehariduse arenguprobleemid II' [The development problems of vocational education II], Eesti Haridusminimsteeriumi pedagoogiline ajakiri: Haridus [Pedagogical journal of the Estonian Ministry of Education: Education], no. 9, 1991, pp. 2-5.

19 R. Neudorf, T. Annus, L. Orro, K. Jõgi, 'National Observatory of Estonia, European Training Foundation,' in The VET System in Estonia: Recent Changes, Challenges and Reform Needs, Sofia, Sibi Publishing House, 1997, pp. 19-20. 
At the beginning of the 1990s, when the system of career counselling was abolished, the minister thought that this was Soviet and should be dissolved ... medical services were taken away from us... it was taken away by the government...

The network of vocational schools was unevenly distributed, concentrating in urban areas. In 1991/1992, 73\% of vocational school students studied in the bigger cities. ${ }^{20}$ There were many types of VET schools (vocational, technical, vocational secondary) but with no clear differences between the names of schools and curriculum. ${ }^{21}$ Almost every school specialised in one area (e.g., Vocational Secondary School no 6, no 21, no 42 in Tallinn specialised in metalwork). Five special schools were opened for prisoners and students who needed special educational conditions. But, employers were not satisfied with the narrow vocational training developed in the Soviet era. ${ }^{22}$ Technical vocational education needed to develop, but generally, attention focused on humanities, which did not provide the necessary base for technical training. ${ }^{23}$

In the mid-1990s, student dropout rates from vocational schools was high (14-15\%) and was attributed to the students' low academic abilities, poor educational success, or unpopular specialities. ${ }^{24}$ However, almost all interviewed teachers mentioned other reasons for students dropping out of school such as decreased social supervision and family support. Many parents went abroad to work and left their children without support and guidance. Students did not learn primary work skills at home and their attitude towards work changed:

${ }^{20}$ M. Kask, 'Viimaste aastate muudatused Eesti kutseharidussüsteemis ning kavandatavad reformid' [The latest year's changes in Estonian VET system and planned reforms], in Baltimaade kutsehariduse ja - koolituse konverents Euroopa riikide vahelise koostöö tähtsus: 22. ja 23. aprillil 1996 Tallinnas, [Baltic states VET conference. The importance of the cooperation between European countries: April 22-23, 1996, Tallinn], Torino, European Training Foundation, 1996.

${ }^{21}$ A. Kõverjalg, 'Kutsehariduse arenguprobleemid' [Development problems of vocational education], Eesti Haridusminimsteeriumi pedagoogiline ajakiri: Haridus [Pedagogical journal of the Estonian Ministry of Education: Education], no. 8, 1991, pp. 2-5; A. Kõverjalg, 'Kutsehariduse arenguprobleemid II' [Development problems of vocational education II], in Eesti Haridusminimsteeriumi pedagoogiline ajakiri: Haridus [Pedagogical journal of the Estonian Ministry of Education: Education], no. 9, 1991, pp. 2-5.

22 Ü.-T. Ojassoo, Riikliku kutseharidussüsteemi kutsekoolid Eestis aastatel 1944-1991 [Vocational schools in the vocational education system in Estonia 1944-1991], Tallinn, Haridus- ja Teadusministeerium, 2005, pp. 16-31.

${ }^{23}$ A. Kõverjalg, 'Kutsehariduse arenguprobleemid' [Development problems of vocational education], Eesti Haridusminimsteeriumi pedagoogiline ajakiri: Haridus [Pedagogical journal of the Estonian Ministry of Education: Education], no. 8, 1991, pp. 2-5; A. Kõverjalg, 'Kutsehariduse arenguprobleemid II' [Development problems of vocational education II], Eesti Haridusminimsteeriumi pedagoogiline ajakiri: Haridus [Pedagogical journal of the Estonian Ministry of Education: Education], no. 9, 1991, pp. 2-5.

${ }^{24}$ M. Kask, 'Viimaste aastate muudatused Eesti kutseharidussüsteemis ning kavandatavad reformid' [The latest year's changes in Estonian VET system and planned reforms], in Baltimaade kutsehariduse ja - koolituse konverents Euroopa riikide vahelise koostöö tähtsus: 22. ja 23. aprillil 1996 Tallinnas, [Baltic states VET conference. The importance of the cooperation between European countries: April 22-23, 1996, Tallinn], Torino, European Training Foundation, 1996. 
...In my opinion, a very big gap came when the Republic of Estonia started and when mothers, fathers all ran across the bay and, I don't know, to work in other places. Then came many divorces and it is still ongoing ... and how the student population has substantial changed ... it is different, how they think, their attitudes ... There are a lot of changes, and I can say, it is because of this old ESSR breakdown and this Republic of Estonia that came in its place ... because of these divorces and broken families, there are no men in these families and boys will come here, many boys need teaching how to turn a screw...

In 1993, some reorganisation of structures and procedures for upgrading the curricula and learning content began. Foreign experts and foreign-funded projects played a significant role in building the Estonian VET system. The major partners were from Finland, Denmark, and Germany. Curricula development began in 1993 with co-operation between the Estonian National School Board and the Royal Danish School of Educational Studies for Vocational Teachers in the project 'Development of Estonian Vocational Education System. The PHARE (one of the main pre-accession assistance financial instruments for countries of Central and Eastern Europe) 1994/1995 VET Reform Programme supported reform at the national and school level in areas of curriculum development, teacher training, upgrading of educational equipment, partnership with EU schools, and VET policy development. Thirteen pilot-schools were involved in development of a module-based curriculum. The project focused on wider preparation in the vocational field that would allow students to specialise in a short time, adjust to changes in the labour market, and participate in further training or retraining after graduation. From 1995-1999, cooperation continued with Irish, Danish, and Finish curriculum developers, and Estonian-Danish cooperation in development of a vocational pre-training curriculum model began. ${ }^{25}$

Vocational teachers were always involved in curriculum development, and many teachers viewed it as an additional administrative obligation that interfered with their everyday work:

...this work with curriculum development, it should be done more by administrative people, it means that a lot of things are pushed on the teacher's shoulders ... And those, who give us things to do should not forget that the teacher's main task, main job is to stand and shine in

\footnotetext{
${ }^{25}$ M. Kask, 'Viimaste aastate muudatused Eesti kutseharidussüsteemis ning kavandatavad reformid' [The latest year's changes in Estonian VET system and planned reforms], in Baltimaade kutsehariduse ja - koolituse konverents Euroopa riikide vahelise koostöö tähtsus: 22. ja 23. aprillil 1996 Tallinnas, [Baltic states VET conference. The importance of the cooperation between European countries: April 22-23, 1996, Tallinn], Torino, European Training Foundation, 1996; Tegevuskava kutseharidussüsteemi arendamiseks Eestis aastatel 2001-2004 [Action Plan for development of VET system in Estonia in 2001-2004], Tallinn, Haridusministeerium, Kutsehariduse ja Tööhõive Seirekeskus, OÜ Sõnasepp, 2001; R. Neudorf, T. Annus, L. Orro, K. Jõgi, 'National Observatory of Estonia, European Training Foundation,' in The VET System in Estonia: Recent Changes, Challenges and Reform Needs, Sofia, Sibi Publishing House, 1997.
} 
front of the class and teach youth and their main job is not some kind of administrative work...

Many vocational schools got partnership schools in foreign countries, and teachers had the opportunity to participate by visiting those schools and share experiences:

...then the Republic of Estonia was established. We had partnership schools everywhere, also in Finland. Finns came to visit us and watched and said, "You are lucky that you had a 50-year Soviet regime here." I didn't understand at all what they wanted to say and what they thought. They thought that we still have the skills of craft. I visited a vocational school in Finland the first time, and I observed the lesson where they taught a boy to screw using a machine. They don't know what a screwdriver is any more and we are going the same way...

It is important to mention that despite curriculum and equipment developments, there was insufficient attention paid to teaching materials. In some vocational fields, teachers used old books from the Soviet era, but mainly they searched for new information and wrote their own teaching materials:

...then there weren't any kinds of books, you had to write teaching materials yourself and this meant that the first lessons were like - you took your teaching materials and students sat nicely in the classroom. They took their [booklets] - silence - everyone wrote things down, because there was nothing to learn from ... At the beginning, it was awful, and you had to do make all teaching materials...

In 1995, preparation of vocational education legislation began. The Vocational Education Institution Act was approved in 1995, but all implementing acts were not prepared. The law focused on the administrative side of school management and regulations for vocational school activities but not the content of curricula. ${ }^{26}$ The Vocational Teacher Statute (1995) introduced the term 'vocational teacher' that eliminated differentiation between theoretical and practical training teaching positions and described pedagogical requirements and work content for vocational teachers. ${ }^{27}$ Some interviewees viewed this change positively because of better integration between theory and practice:

\footnotetext{
${ }^{26}$ M. Kask, 'Viimaste aastate muudatused Eesti kutseharidussüsteemis ning kavandatavad reformid' [The latest year's changes in Estonian VET system and planned reforms], in Baltimaade kutsehariduse ja - koolituse konverents, Euroopa riikide vahelise koostöö tähtsus: 22. ja 23. aprillil 1996 Tallinnas, [Baltic states VET conference. The importance of the cooperation between European countries: April 22-23, 1996, Tallinn], Torino, European Training Foundation, 1996, p. 15; R. Neudorf, T. Annus, L. Orro, K. Jõgi, 'National Observatory of Estonia, European Training Foundation,' in The VET System in Estonia: Recent Changes, Challenges and Reform Needs, Sofia, Sibi Publishing House, 1997, p. 26.

27 'Kutseõpetaja statuut' [Vocational Teacher Statute], Riigi Teataja Lisa [Supplement to the State Gazette], no. 49, 1995. Available: https://www.riigiteataja.ee/akt/30820 (accessed 11.04.2020)
} 
...then the same teacher started teaching it all [theory and practice]. And of course, it was easier for work practice; since I had taught the theory, I knew exactly what I was going to demand in practice, and I had a clear picture of what each of them knew and was able to do and how...

In 1996, the Department of Vocational Education was restored in the Ministry of Education and vocation schools were internally differentiated, allowing studies at different levels based on previous education and time: 1-3 years after basic education (ISCED3/3C), at least 4 years after basic education with uppersecondary general education (ISCED3/3A), post-secondary technical education (ISCED5/3A), 1-3 years after upper-secondary education (ISCED3/4B), and post-secondary technical education (ISCED5/5B). Vocational studies contained theory and practical training, supportive theoretical training, and compulsory general subjects; $53 \%$ of vocational schools offered studies in Estonian only, $19 \%$ in Russian only, and the remaining $27 \%$ used both languages. A total of $67 \%$ of students studied in Estonian. ${ }^{28}$

The popularity of vocational subjects changed from $1992 / 1993$ to $1995 / 96$, and the percentage of students in vocational schools increased from $6.9 \%$ to $10.4 \%$ in trade and business and from $9.9 \%$ to $13.3 \%$ in service, catering and tourism. In contrast, the numbers decreased in industry and crafts $(59.2 \%$ to $50.5 \%)$ and in agriculture, forestry and fisheries (9.9\% to 6\%). ${ }^{29}$ A forestry teacher described how these trends influenced her work:

...[during the Soviet period] those, who wanted to come, were much more than we were able to take ... I don't know how there were enough students then ... maybe they really aren't interested ... The remaining groups were small...

Legislative framework for VET, 1997-2000. In 1997, the National Observatory of Vocational Education and Employment was established to observe developments in VET, which intensified on the national level. Constructive dialogue between trainers and social partners began and legislation was passed. In 1998, the Vocational Institution Act and Conceptual Basis for Vocational Education were adopted. Also, the General Requirements for the National

${ }^{28}$ Reviews of National Policies for Education: Estonia, OECD, 2001, p. 134; M. Kask, 'Viimaste aastate muudatused Eesti kutseharidussüsteemis ning kavandatavad reformid' [The latest year's changes in Estonian VET system and planned reforms], in Baltimaade kutsehariduse ja - koolituse konverents Euroopa riikide vahelise koostöö tähtsus: 22. ja 23. aprillil 1996 Tallinnas, [Baltic states VET conference. The importance of the cooperation between European countries: April 22-23, 1996, Tallinn], Torino, European Training Foundation, 1996.

${ }^{29}$ M. Kask, 'Viimaste aastate muudatused Eesti kutseharidussüsteemis ning kavandatavad reformid' [The latest year's changes in Estonian VET system and planned reforms], in Baltimaade kutsehariduse ja - koolituse konverents Euroopa riikide vahelise koostöö tähtsus: 22. ja 23. aprillil 1996 Tallinnas, [Baltic states VET conference. The importance of the cooperation between European countries: April 22-23, 1996, Tallinn], Torino, European Training Foundation, 1996, pp. 16-35. 
Curricula of Vocations, Occupations and Specialities was approved, ${ }^{30}$ which stated that the curriculum should contain vocational practical and theoretical training, subjects for social skills, electives, and in some cases, general secondary education..$^{31}$ School curricula had to conform to the national curriculum, but national curricula was lacking a long time. ${ }^{32}$ The aims of VET were to create opportunities for self-development, offer wider professional skills, and to be effective, flexible, of high-quality, collaborative, and available.

In addition to curricula development, attention was paid to VET staff development through efficient use of resources, training in larger regional VET centres, and diversifying the form of ownership of vocational institutions (municipal and private). ${ }^{33}$ The number of state VET institutions decreased because of consolidation of small VET schools. ${ }^{34}$

To increase VET flexibility, learning opportunities were created for adults and young people without basic education and for people with disabilities, who could acquire vocational education and which gave them skills to get a job. VET reforms in 1999/2000 introduced vocational secondary education based on basic education, vocational secondary education based on general secondary education, and professional higher education. ${ }^{35}$ The time for studies in vocational secondary schools based on basic education decreased: they lasted at least 120 weeks and included at least 50\% vocational training and studies in general education for 50 weeks. Studies based on upper-secondary education lasted 40-100 weeks and included 85\% vocational training and six weeks of general education studies. ${ }^{36}$ But teachers noted that shorter periods weren't enough for younger students' professional growth:

${ }^{30}$ Tegevuskava kutseharidussüsteemi arendamiseks Eestis aastatel 2001-2004 [Action Plan for development of VET system in Estonia in 2001-2004], Haridusministeerium, Kutsehariduse ja Tööhõive Seirekeskus, 2001.

31 'Kutse-, eri- ja ametialade riiklike õppekavade üldnõuete kinnitamine' [Ratification of the General Requirements for the National Curriculum of vocations, occupations and specialities], Riigi Teataja I [The State Gazette I], vol. 94, no. 1504, 1998. Available: https://www. riigiteataja.ee/akt/76297 (accessed 11.04.2020)

${ }^{32}$ M. Kask, 'Viimaste aastate muudatused Eesti kutseharidussüsteemis ning kavandatavad reformid' [The latest year's changes in Estonian VET system and planned reforms], in Baltimaade kutsehariduse ja - koolituse konverents Euroopa riikide vahelise koostöö tähtsus: 22. ja 23. aprillil 1996 Tallinnas, [Baltic states VET conference. The importance of the cooperation between European countries: April 22-23, 1996, Tallinn], Torino, European Training Foundation, 1996.

${ }^{33} \mathrm{H}$. Zelloth, Monograafia Eesti kutsehariduse, täiendkoolituse ning tööhõiveteenuste süsteemide ja struktuuride kohta [Monograph about the systems and structures of vocational education, further education and employment of Estonia], Tallinn, Sihtasutus Eesti Kutsehariduse Reform, INNOVE Elukestva Õppe Arendamise SA, 2003, pp. 17-20.

${ }^{34}$ Tegevuskava kutseharidussüsteemi arendamiseks Eestis aastatel 2001-2004 [Action Plan for development of VET system in Estonia in 2001-2004], Haridusministeerium, Kutsehariduse ja Tööhõive Seirekeskus, 2001.

35 1996-2006: Kutseharidus [1996-2006: Vocational education], Tallinn, Statistikaamet, 2007, p. 55.

${ }^{36}$ Tegevuskava kutseharidussüsteemi arendamiseks Eestis aastatel 2001-2004 [Action Plan for development of VET system in Estonia in 2001-2004], Haridusministeerium, Kutsehariduse ja Tööhõive Seirekeskus, 2001. 
...there is not enough time ... I liked the period when [studies] were four years after basic school ... we had similar feelings [with colleagues], when three years were over, the fourth year I had the feeling that now we can start working. It gave them more experience, gave them speed...

There were also other problems in school-based vocational education because there were no regulations for practical training at schools and in businesses. In addition, the aims of practical training were too declarative. ${ }^{37}$

...you have now practical training, but what was needed was to go through and how ... there was no difference ... The students visited more sites and worked there, but the students were given [teacher names activities] such general work, not something that would later put bread on the table - basically busy work was given...

Development of teaching staff was necessary because many teachers had insufficient pedagogical education. They were unfamiliar with modern technology and teaching methods and their teaching practices were mainly academic, lacking integration of theory and practice. ${ }^{38}$ Even experienced interviewees noted that changes in pedagogy were greater on paper (in curricula) and teaching had not changed much, but technology had:

In general, if you start to think, then the wording or how things were written down, new words, expressions [changed] in pedagogy. Actually, behind the expression, if you start to study it, the content is the same. ... But if you start to think then the equipment, technical tools, and these technologies, how things are done, there are actually more changes than in pedagogy.

In 1999, the Chamber of Commerce and Industry began creation of a professional qualification system and professional councils. ${ }^{39}$ Development of professional standards and national curricula began. The Professions Act (2000) provided the basis for development of professional qualification requirements. ${ }^{40}$ By 2000 , all vocational schools were following modular curricula and $30 \%$ of these were consistent with professional standards. ${ }^{41}$

....at the end of the 90s, things were already... the common things were in vocational schools. [But also] there were differences ... when these

37 'Õppepraktika korraldus kutseõppeasutustes' [Organisation of the traineeships in vocational education institution], Riigikontrolli kontrolliaruanded [Audit reports of the National Audit Office], no. 12-7/045, 2002.

${ }^{38}$ Reviews of National Policies for Education: Estonia, OECD, 2001, p. 142.

${ }^{39} \mathrm{~K}$. Loogma, 'Europeanization in VET Policy as a Process of Reshaping the Educational Space, International Journal for Research in Vocational Education and Training, vol. 3, no. 1, 2016, pp. 16-28.

${ }^{40}$ Kutseseadus [Proffessions Act], Riigi Teataja I [The State Gazette I], vol. 3, no. 7, 2001.

${ }^{41}$ Tegevuskava kutseharidussüsteemi arendamiseks Eestis aastatel 2001-2004 [Action Plan for development of VET system in Estonia in 2001-2004], Haridusministeerium, Kutsehariduse ja Tööhõive Seirekeskus, 2001. 
common standards and things came, naturally it created a common understanding of what to do and how...

Employers' associations played a significant role in construction of the vocational qualifications system, but small and medium-sized companies, the growth sector in Estonian employment, were not sufficiently represented. ${ }^{42}$ Cooperation between businesses and schools had improved, but teachers remembered how each company jealously guarded their specialised technological practices and refused to share them with the schools who were educating and training the workforce: "...before it really used to be that you didn't get any technology or any information from the company...”

The most popular fields of study were commercial and business administration, engineering and trade, manufacturing and processing, architecture and construction, and personal services; from 1999/2000 on, computer sciences began to increase. ${ }^{43}$

Pre-joining period, 2001-2004. In 2001, the Action Plan for the Estonian VET System 2001-2004 was adopted. The purpose was to prepare a competitive workforce for Estonian and international labour markets while providing both social and occupational readiness to work. Development of the curricula and the reorganisation of the network of vocational schools continued. Attention turned to guaranteeing learning opportunities, ensuring quality of training and development of the VET teacher training system. In 2002, Requirements for Teacher Qualification were introduced, which demanded from many vocational teachers higher education qualification levels. ${ }^{44}$

To ensure quality of training, more attention was paid to practical training in businesses. In 2001, vocational schools had to sign contracts for practical training between businesses and students, but there were no regulations for organising or financing this practice. Most students found businesses independently or through acquaintances or relatives; school initiative was minimal. ${ }^{45}$ Teachers experienced problems of unmotivated enterprises caused by lack of financing because supervision was an unpaid, additional obligation: "When the student goes [to a workplace for practice], ... she needs a supervisor. But this supervisor wastes her time, loses working hours and earnings ..."

The purpose of the school network reform was to establish multifunctional VET regional centres that would specialize according to local employment

${ }^{42}$ Reviews of National Policies for Education: Estonia, OECD, 2001.

43 1996-2006: Kutseharidus [1996-2006: Vocational education], Tallinn, Statistikaamet, 2007, p. 79.

${ }^{44}$ Tegevuskava kutseharidussüsteemi arendamiseks Eestis aastatel 2001-2004 [Action Plan for development of VET system in Estonia in 2001-2004], Haridusministeerium, Kutsehariduse ja Tööhõive Seirekeskus, 2001.

45 'Õppepraktika korraldus kutseõppeasutustes' [Organisation of the traineeships in vocational education institution], Riigikontrolli kontrolliaruanded [Audit reports of the National Audit Office], no. 12-7/045, 2002. 
needs. ${ }^{46}$ However, local governments were not interested in running vocational schools, and in 2003/2004, there was only one municipal vocational school, and the number of state vocational schools decreased because of reorganisation consolidating small VET schools. ${ }^{47}$

Teacher experience with reorganisation of the school network indicated that they felt insecure because of the uncertain future of their school and job, or they emphasised that large VET centres had decreased communication and interaction with colleagues and emphasis on student-centred approach: "...decreasing costs, but in the bigger schools we have less opportunity to pay attention to students and their individuality ..."

Better integration of general and vocational education was created in 2001 with the introduction of 'Pre-vocational training' (ISCED2) as a vocational elective in general schools. Admission to 'Vocational secondary education' was after either basic education (ISCED3B) or general upper-secondary education (ISCED3/4B). Vocational secondary education after basic education prepared students for trades for at least three years and gave them the possibility of entering the labour market or attending higher education if they passed state examinations. Vocational secondary education after general upper-secondary education prepared students for technically more demanding work for 1 to 2.5 years. In 2002/2003, 60\% of vocational institutions provided learning programmes in Estonian and 20\% in Russian. ${ }^{48}$ In 2003, apprenticeship training was started by PHARE 2002.49

The most popular fields in 2004 were technical specialities, business and administration, and personal services. ${ }^{50}$ But the popularity of VET was still low and after graduating basic school, only $26 \%$ of young people entered vocational schools in $2001 .^{51}$ In 2002/2003, only $9,4 \%$ of all students in Estonia attended vocational secondary education..$^{52}$ In 2004/2005, about $29 \%$ of basic school graduates and $13 \%$ of upper-secondary general school graduates continued their studies in vocational schools. ${ }^{53}$ This was also experienced by teachers:

${ }^{46} \mathrm{~K}$. Loogma, 'Europeanization in VET Policy as a Process of Reshaping the Eeducational Space,' International Journal for Research in Vocational Education and Training, vol. 3, no. 1, 2016, pp. 16-28.

${ }^{47}$ Eesti kutseharidussüsteemi arengukava aastateks 2005-2008 [Development plan for the Estonian VET system 2005-2008], Haridus- ja Teadusministeerium, 2005, p. 43.

${ }^{48} \mathrm{H}$. Zelloth, Monograafia Eesti kutsehariduse, täiendkoolituse ning tööhõiveteenuste süsteemide ja struktuuride kohta [The monograph about the systems and structures of vocational education, further education and employment of Estonia], Tallinn, Sihtasutus Eesti Kutsehariduse Reform, INNOVE Elukestva Õppe Arendamise SA, 2003, pp. 20-38.

49 1996-2006: Kutseharidus [1996-2006: Vocational education], Tallinn, Statistikaamet, 2007.

${ }^{50}$ Eesti kutseharidussüsteemi arengukava aastateks 2005-2008 [Development plan for the Estonian VET system 2005-2008], Haridus- ja Teadusministeerium, 2005, p. 39.

${ }^{51}$ 1996-2006: Kutseharidus [1996-2006: Vocational education], Tallinn, Statistikaamet, 2007, p. 55.

${ }^{52} \mathrm{H}$. Zelloth, Monograafia Eesti kutsehariduse, täiendkoolituse ning tööhõiveteenuste süsteemide ja struktuuride kohta [The monograph about the systems and structures of vocational education, further education and employment of Estonia], Tallinn, Sihtasutus Eesti Kutsehariduse Reform, INNOVE Elukestva Õppe Arendamise SA, 2003, p. 20.

${ }^{53}$ 1996-2006: Kutseharidus [1996-2006: Vocational education], Tallinn, Statistikaamet, 2007, p. 13. 
“...it's still low, the popularity of vocational education. ... We all keep saying that we need a workforce, but when someone goes to a VET school, then it's like, like something second-rate..."

VET development was already affected by European strategies and Estonia joined the Copenhagen Declaration in 2002, which was the first great initiative of VET policy in Europe..$^{54}$

\section{Conclusion}

In the early 1990s, VET started almost from scratch: all structures were liquidated as inappropriate baggage from the Soviet regime. Change focused at the national level for development of the VET system, its structures and effectiveness. It seemed that the best results could be achieved by reducing state support and resources. From 1993-2004, vocational education was underfinanced, compared with general and higher education. ${ }^{55}$ The number of state vocational schools decreased from 77 to 53 and municipal schools from 3 to 1 , but private schools increased from 0 to 19. In 2004, there were 73 vocational schools with 28183 students in Estonia. However, high-quality vocational education is expensive and requires money for equipment and involvement of businesses. Before 2003-2004, VET policy initiatives were still quite random; many goals were not achieved in 2001-2004, ${ }^{56}$ and systematic activities only began with the 2005-2008 development plan for Estonian VETs. ${ }^{57}$

There have been many national changes in vocational education, but not all influenced everyday pedagogical work. Many changes emerged, which hampered teaching such as the shortened period of studies and reorganisation of the school network. In the midst of all the changes were vocational teachers who valued the student and the learning and teaching process above the systems, structures, and numbers. They implemented ideas of vocational pedagogy, valuing diligence, hard work, and vocation. Vocational teachers had positive experiences with curricula development and standardisation, which created a common basis and understanding of the learning content. Some teachers had positive experiences with changes in vocational pedagogy such as teaching more coherent theory and practice or clarity and comparability of curriculum as a result of reforms and professional standards. But many teachers viewed changes rather negatively. They experienced more formal than substantive

${ }^{54}$ Eesti kutseharidussüsteemi arengukava aastateks 2005-2008 [Development plan for the Estonian VET system 2005-2008], Haridus- ja Teadusministeerium, 2005, p. 11.

${ }^{55}$ 1996-2006: Kutseharidus [1996-2006: Vocational education], Tallinn, Statistikaamet, 2007, p. 52.

${ }^{56}$ Eesti kutseharidussüsteemi arengukava aastateks 2005-2008 [Development plan for the Estonian VET system 2005-2008], Haridus- ja Teadusministeerium, 2005, p. 37.

${ }^{57}$ Eesti kutsehariduspolitika arengud aastatel 2002-2008 [Developments of vocational education policy in Estonia in 2002-2008], Tallinn, Kutsehariduse Seirekeskus, 2008, p. 4; H. Zelloth, Monograafia Eesti kutsehariduse, täiendkoolituse ning tööhõiveteenuste süsteemide ja struktuuride kohta [The monograph about the systems and structures of vocational education, further education and employment of Estonia], Tallinn, Sihtasutus Eesti Kutsehariduse Reform, INNOVE Elukestva Õppe Arendamise SA, 2003, p. 36. 
curriculum development, lack of career counselling for youth, and negative influences of reducing resources and time for the student-centred approach. In conclusion, despite significant reorganisation, changes in VET regulations, and standardisation, long-time teachers focused on changes in the student population and teacher ability to support the development of students' professional knowledge, skills, and attitudes, which was the main purpose of vocational pedagogy at the time.

Acknowledgements. The article is part of the national research project IUT18-2 Teacher professionality and professionalism in changing contexts (1.01.2014-31.12.2019) supported by the Estonian Research Council. 